\title{
GROUND WATER QUALITY AND WATER QUALITY INDEX OF DWARKA DISTRICT OF NATIONAL CAPITAL OF INDIA
}

\author{
Ravi Kant Dubey ${ }^{1}$, Jakir Hussain ${ }^{2}$, Nishchay Malhotra ${ }^{3}$, Ankur Mehta ${ }^{4}$ \\ ${ }^{1}$ Student, Dept. of Environmental Engineering, CBPGEC New Delhi, India \\ ${ }^{2}$ National River Water Quality Laboratory, Central Water Commission, New Delhi, India \\ ${ }^{3}$ Student, Dept. of Environmental Engineering, CBPGEC New Delhi, India \\ ${ }^{4}$ Student, Dept. of Environmental Engineering, CBPGEC New Delhi, India
}

\begin{abstract}
Assessment of water quality of drinking water supplies has always been paramount in the field of environmental quality management. Groundwater quality of Dwarka has a special significance and needs greater attention of all concerned since it is the only major source for domestic, consumption. In this work we have estimated the ground water quality of Dwarka. Groundwater quality of Delhi needs greater attention because there is a continuous decline in water level and quality due to rapid urbanization and industrialization. The present study was attempted to access the groundwater quality of Dwarka district in Delhi. The samples of the ground water are collected manually from the bore wells which were approximately equally distributed all over 29 sectors and nearby areas. The samples were analyzed using standard procedures in the laboratory. The water quality index is a single number that expresses the quality of water by integrating the water quality variables. Its purpose is to provide a simple and concise method for expressing the water quality for different usage. Water Quality Index, has been calculated for the Dwarka sub-city and was studied for the suitability of water for drinking purposes and the results showed that the ground water quality was unfit for drinking in almost all of the areas scoring a water quality index greater than 110.
\end{abstract}

Keywords: Water Quality, Ground water, Water Quality Index, Delhi

\section{INTRODUCTION}

India, like any other developing country of the world, is facing increasing environmental problems. The vast population and ever increasing industrial activities in India, makes its water resources more vulnerable to water quality deterioration. The groundwater resources are at higher risk as its remediation is very difficult. The major anthropogenic activities for continuous groundwater quality deterioration are urbanization, industrialization, and agriculture run off. Also the problem of drinking water contamination, water conservation, and water quality management has assumed a very important role for sustainable development of countries, such as India. Presently, water quality assessment is carried out by determining various abiotic (physicochemical) and biotic (biological) parameters, either individually or in combination. Determination of water quality is very important for knowing the suitability of water for various purposes. Use of Water Quality Index (WQI) to determine the water quality of aqua resources is considered as one of the most effective tool for comparing water resources. The WQI was developed in the 1970s by the Oregon Department of Environmental Quality for the purpose of summarizing and evaluating water quality trends and status (ODEQ, 2004).
The objective of the paper is to evaluate and assess the groundwater quality of Dwarka district of National capital of India.

\section{STUDY AREA}

Dwarka is a sub-city and a part of the urban extension envisaged in the Master Plan for Delhi 2001, based on the implementation of the three mega projects of Rohini, Dwarka and Narela. Dwarka is a recent urban extension located at the periphery of the current urban center of Delhi. The Dwarka sub-city is a part of the ambitious schemes for urban extension envisaged in the Master Plan for Delhi 2011 (MPD-2001) released by the Delhi Development Authority (DDA) in 1991. The MPD 2001 projected an increase in the population of the National Capital Territory of Delhi (NCT Delhi) from 9.42 Million for the year 1991 to 12.8 Million for the year 2001. 


\begin{tabular}{|l|l|}
\hline \multicolumn{2}{|c|}{ Population of Dwarka - 2,292,000 i.e., 2.292 million } \\
\hline Total area of Dwarka - 56.48 sq. Km or 5648 ha. \\
\hline Dwarka project is planned with 29 sectors. \\
\hline The land use distribution of Dwarka is - \\
\hline Gross Residential & $48.54 \%$ \\
\hline Commercial & $7.05 \%$ \\
\hline Government & $0.94 \%$ \\
\hline Public / Semi-Public & $6.20 \%$ \\
\hline Recreational & $19.94 \%$ \\
\hline Transport & $14.33 \%$ \\
\hline Utilities & $3.00 \%$ \\
\hline
\end{tabular}

\section{SAMPLING SITES}

Sampling and chemical analysis of underground water of Dwarka Sub-city of Delhi and near by areas was performed . For the present studies water samples from twenty six (26) different locations were collected in month of June, 2013. This month was selected in a view to assess the quality of underground water before monsoon. All sampling sites were selected in a view to cover entire area of Dwarka sub-city and area near Najafgarh Drain.

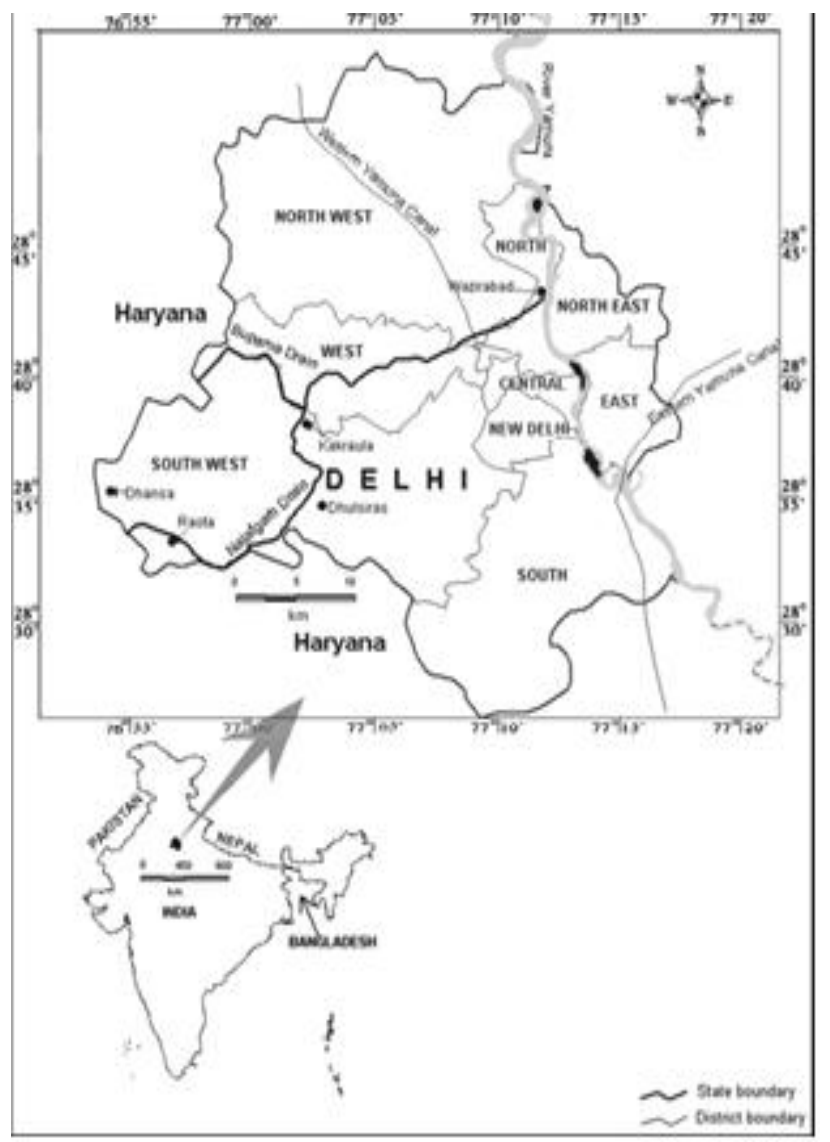

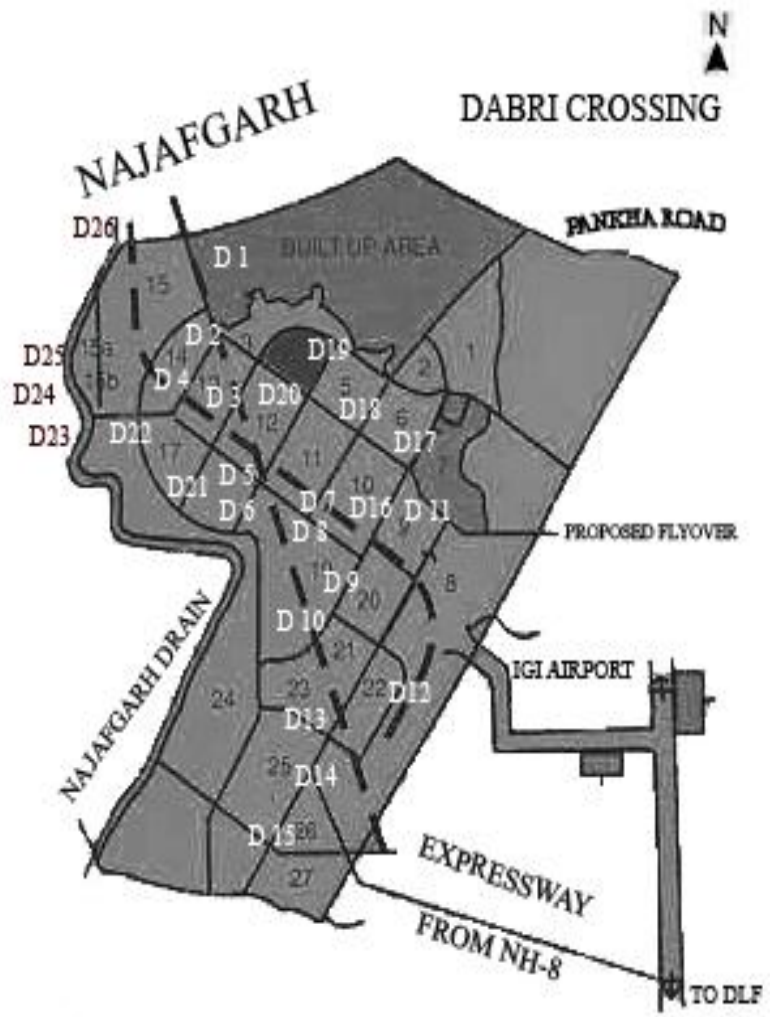

Fig.-1: Study Area

Table -1: Sample Code and Sampling Location

\begin{tabular}{|l|l|}
\hline $\begin{array}{l}\text { Sample } \\
\text { Code }\end{array}$ & Location \\
\hline D 1 & Kakrola Gaon \\
\hline D 2 & Sector-14 \\
\hline D 3 & Sector-13 \\
\hline D 4 & Sector-14 \\
\hline D 5 & Sector-18B (Shree apartments KK) \\
\hline D 6 & Sector-18B (Shree apartments BTH) \\
\hline D 7 & Cremation Ground Near temple \\
\hline D 8 & Sector-19, Pocket1 Pump House \\
\hline D 9 & Sector 19, DDA Park \\
\hline D 10 & Sector-19, Police Station \\
\hline D 11 & Sector 9, Asia Centre \\
\hline D 12 & Sector 22, DDA Park \\
\hline D 13 & Sector 26 \\
\hline D 14 & Near Bharthal Chowk Village \\
\hline D 15 & MCD School Pochanpur \\
\hline D 16 & Sector-10, Health Centre \\
\hline D 17 & Sector-6, Dwarka Central Nursary \\
\hline D 18 & Sector 5 \\
\hline D 19 & Sector 4 \\
\hline D 20 & Sector 12 \\
\hline D 21 & Sector 17 \\
\hline
\end{tabular}




\begin{tabular}{|l|l|} 
D 22 & Sector 16, CRPF \\
\hline D 23 & Najafgarh Drain Borewell \\
\hline D 24 & Over drain Cons NJFGRH Drain \\
\hline D 25 & NAJaFGRH Drain 66 KV grid Constctionr \\
\hline D 26 & Deepak Vihar, Vikas Nagar \\
\hline
\end{tabular}

\section{MATERIALS AND METHODS}

Total twenty six (26) ground water samples from different bore wells and pumps were collected in polyethylene bottles during June, 2013. Grab sampling has been adopted to collect groundwater samples. The samples were transported in a cool box to be stored under suitable temperature until analysis. The necessary precautions were adopted during sampling (Brown et al., 1974). The parameters $\mathrm{pH}$, electrical conductivity (EC) and total dissolved solids (TDS) were analyzed or measured in the field at the time of sampling and crosschecked in laboratory while carbonate $\left(\mathrm{CO}_{3}^{-2}\right)$, bicarbonate $\left(\mathrm{HCO}_{3}^{-}\right)$, total hardness $(\mathrm{TH})$, ammonia $\left(\mathrm{NH}_{3}\right)$, nitrate $\left(\mathrm{NO}_{3}{ }^{-}\right)$, nitrite $\left(\mathrm{NO}_{2}{ }^{-}\right)$, phosphate $\left(\mathrm{PO}_{4}{ }^{-2}\right)$, silicate $\left(\mathrm{SiO}_{3}\right)$, fluoride $\left(\mathrm{F}^{-}\right)$, sulfate $\left(\mathrm{SO}_{4}^{-2}\right)$ chloride $\left(\mathrm{Cl}^{-}\right)$, calcium $\left(\mathrm{Ca}^{+2}\right)$, magnesium $\left(\mathrm{Mg}^{+2}\right)$, sodium $\left(\mathrm{Na}^{+}\right)$, potassium $\left(\mathrm{K}^{+}\right)$, Boron (B) and total dissolved solids (TDS) were analyzed in the laboratory adapting standard methods (APHA, 2012).

\section{RESULT AND DISCUSSION}

The results of chemical analysis of groundwater were compared with the drinking water standards IS: 10500: 2012 to arrive at conclusions.

\section{$5.1 \mathrm{pH}$}

The $\mathrm{pH}$ value is the measured of relative acidity and alkalinity. The $\mathrm{pH}$ of the water mainly depends upon i) temperature and nature of water (ii) relative concentration of acids and of bases and (iii) degree of dissociation of acids or association of bases. The BIS standards reveal that for domestic use the $\mathrm{pH}$ values of the groundwater should range between 6.5 and 8.5. The highest value of 8.4 is measured in sample D17 of Dwarka Sector 6, whereas the lowest value of 6.83 is measured in sample D1 of Kakrola Gaon. From the results it is clear that the $\mathrm{pH}$ of water is mainly due to the equilibrium between free $\mathrm{CO} 2$ and bicarbonate ions. The results of $\mathrm{pH}$ for all groundwater sources, however, are in agreement with the range values of 6.5-8.5 determined by IS, 10500, 2012 standards.

\subsection{Electrical Conductivity (EC) and Total Dissolved}

\section{Solids}

Conductivity is used as an indicator of the abundance of dissolved inorganic species or total concentration of ions (Banar, et al., 2006). Total dissolved solids and electrical conductivity of water has a high degree of correlation $(>0.95)$ as both parameters indicate the amount of dissolved solid
(Hussain et al., 2001; Tiwari and Ali, 1988). Electrical Conductively (EC) values show variety results between groundwater sources. The highest value $14580 \mu \mathrm{mhos} / \mathrm{cm}$ is obtained at Dwarka Sector 12, whereas the lowest value 322 $\mu \mathrm{mhos} / \mathrm{cm}$ is obtained at the Dwarka Sector 6.

A total dissolved solid is a measure of total concentration of all constituents dissolved in water and has bearing on its color, odour and taste. Water with high TDS values has laxative effects on human system and does not quench thirst. For drinking water, Bureau of Indian Standards 10500, 2012 has prescribed the highest desirable limit of $500 \mathrm{mg} / \mathrm{l}$ but in the absence of alternative sources of supply, this limit may be extended upto $2000 \mathrm{mg} / \mathrm{l}$. Total dissolved solids of the study area found in the range of 209 to $9477 \mathrm{mg} / \mathrm{l}$. The highest concentration $(9477 \mathrm{mg} / \mathrm{l})$ is measured in D20 of Dwarka Sector 12, whereas the lowest concentration $(209 \mathrm{mg} / \mathrm{l})$ measured at D17 Dwarka Sector 6. From Table it is clear that two sources (D-7,17) have total dissolved solids value within maximum desirable limits $(500 \mathrm{mg} / \mathrm{l})$ but 7 sources (D$6,11,18,22,23,24,25)$ have the value between maximum desirable limit and maximum permissible limits $(2000 \mathrm{mg} / \mathrm{l})$. Remaining all the sources are out of maximum permissible limits hence unsuitable for drinking purposes.

\subsection{Total Hardness (TH)}

The principal natural sources of hardness in water are sedimentary rocks and seepage and runoff from soils. In general, hard waters originate in areas with thick topsoil and limestone formations. Groundwater is generally harder than surface water. Total hardness is normally expressed as the total concentration of $\mathrm{Ca}^{2+}$ and $\mathrm{Mg}^{2+}$ in $\mathrm{mg} / \mathrm{l}$, equivalent $\mathrm{CaCO}_{3}$. Calcium $\left(\mathrm{Ca}^{2+}\right)$ and magnesium $\left(\mathrm{Mg}^{2+}\right)$ are the important parameters for total hardness. The total hardness of the study area is found in the range of 144 to $3808 \mathrm{mg} / \mathrm{l}$. The highest value of $3808 \mathrm{mg} / \mathrm{l}$ is observed in ground water source D-8 of Dwarka Sector 8 while the minimum value of $144 \mathrm{mg} / 1$ is in sample D19 of Dwarka Sector 4. Total hardness of two sources (D-5 and D-19) is found within maximum desirable limit (300 mg/l) but nine sources (D-3, 10, 11, 12, 17, 18, 20, $23,25)$ are between maximum desirable limit and maximum permissible limit $(600 \mathrm{mg} / \mathrm{l})$.

Sawyer classified the water on the basis of hardness as shown in table 2. According to this classification no source is soft and moderately hard. Source D-5 is hard and remaining twenty four (24) sources are very hard hence not suitable for domestic purpose. 
Table -2: Classification of ground water for domestic purpose (Sawyer)

\begin{tabular}{|c|c|c|c|c|}
\hline $\begin{array}{l}\text { S. } \\
\text { No. }\end{array}$ & Class & $\begin{array}{l}\text { Hardness as } \\
\mathrm{CaCO} 3 \text { ( in } \\
\mathrm{mg} / \mathrm{l} \text { ) }\end{array}$ & $\begin{array}{l}\text { No. of } \\
\text { samples }\end{array}$ & $\begin{array}{l}\text { Detail of } \\
\text { sources }\end{array}$ \\
\hline 1 & Soft & Below 75 & - & \\
\hline 2 & Moderately & $75-150$ & 1 & D19 \\
\hline 3 & Hard & $150-300$ & 1 & D-5 \\
\hline 4 & $\begin{array}{l}\text { Hard } \\
\text { Very Hard }\end{array}$ & Above 300 & 24 & $\begin{array}{l}\text { All other } \\
\text { sample }\end{array}$ \\
\hline
\end{tabular}

\subsection{Calcium and Magnesium}

Multivalent cations, particularly magnesium and calcium are often present at a significant concentration in natural waters. These ions are easily precipitated and in particular react with soap to make it difficult to remove scum. Calcium is an essential element required for good health and its daily requirement varies from 0.7-2.0 gm. Insufficient amount of calcium may induce adverse physiological effects. On the contrary excess amount of calcium in body results in formation of urinary bladder stone and irritation in urinary passage. Bureau of Indian Standards IS:10500, 2012 have recommended the highest desirable limit of $75 \mathrm{mg} / \mathrm{l}$ and maximum permissible limit of $200 \mathrm{mg} / \mathrm{l}$. The Calcium concentration in groundwater of the study area ranged from 14.69 (D-14) to 292.9 (D-20) mg/l. Eight ground water source (D-2, 3,10,12,16, 18,19,21) have the calcium concentration above the BIS limit.

It is an essential to plant and animal nutrition. In some aspects of water chemistry, calcium and magnesium may be considered as having similar effects, as in their contributions to the property of hardness. Magnesium is essential as an activator of many enzyme systems (WHO, 1997). The geochemical behaviour of magnesium is substantially different from that of calcium. Magnesium ions are smaller than sodium or calcium ions and can be accommodated in the space at the center of six octahedrally coordinated water molecules. In groundwater, the calcium content generally exceeds the magnesium content, in accordance with their relative abundance in rocks but contrary to their relative solubilities of their salts. Magnesium is an important component of basic igneous rocks such as dunites, pyroxenites and amphibolites; volcanic rocks such as basalts, metamorphic rocks such as talc and tremolite-schists; and sedimentary rocks such as dolomite. Olivine, augite, biotite, hornblende, serpentine and talc are some major magnesium-bearing minerals. The concentration of magnesium ions varied from 16 to $56 \mathrm{mg} / \mathrm{l}$. Most of the samples are with in the limit prescribed by BIS except these ground water samples (D-2, 3, 10, 12, 16, 19, 20). The high concentration of magnesium ion may cause laxative effect, while deficiency may cause structural and functional changes.

\subsection{Sodium and Potassium}

The concentration of sodium $\left(\mathrm{Na}^{+}\right)$in water samples varied from 4 to $2417 \mathrm{mg} / \mathrm{l}$. The highest concentration is measured in sample D20 of Dwarka Sector 20 and the lowest concentration is measured in sample D16 of Dwarka Sector 10. The high concentration of $\mathrm{Na}^{+}$may pose a risk to persons suffering from cardiac, renal and circulatory disease. The concentration of potassium in the water samples varied from 1.0 to $32 \mathrm{mg} / \mathrm{l}$. the highest concentration of potassium is observed to be 31.90 $\mathrm{mg} / \mathrm{l}$ in the sample D-3 of Dwarka Sector 13 while the least value observed is $1.0 \mathrm{mg} / \mathrm{l}$ in sample D-24 of Najafgarh drain side. Large amount of these ions gives a salty taste to water when combined with chlorides. Moderate quantities have a little effect on the usefulness of water for most of the purposes.

\subsection{Fluoride:}

The concentration of fluoride in groundwater is principally governed by climate, the composition of the host rock and hydrogeology (Sujatha, 2003; Hussain et al., 2000, 2003, 2004, 2005, 2007, 2010, 2012; Arif 2012). Fluorite is the principal bearer of fluoride and is found in granite, gneiss, and pegmatite (Rama Rao, 1982). Fluoride is released to the soil and groundwater by the process of weathering of primary rock or leaching of landfill contaminants (Sujatha, 2003). When fluoride is released into the soil and groundwater, the concentration may increase until saturation is reached (Handa, 1975). The alkaline water can mobilize fluoride from fluorite $\left(\mathrm{CaF}_{2}\right)$ with the simultaneous precipitation of $\mathrm{CaCO}_{3}$ because the solubility of $\mathrm{CaF}_{2}$ increases with an increase in $\mathrm{NaHCO}_{3}$ rather than with salts $\mathrm{NaCl}, \mathrm{Na}_{2} \mathrm{SO}_{4}, \mathrm{MgCl}_{2}$ and $\mathrm{MgSO}_{4}$ (Ramamohan Rao et al. 1993; Saxena and Ahmad 2001, 2003).

$$
\begin{gathered}
\mathrm{CaF}_{2}+2 \mathrm{HCO}_{3}^{-} \rightarrow \mathrm{CaCO}_{3}+2 \mathrm{~F}^{-}+\mathrm{H}_{2} \mathrm{O}+\mathrm{CO}_{2} \\
\mathrm{CaF}_{2}+2 \mathrm{NaHCO}_{3} \rightarrow \mathrm{CaCO}_{3}+2 \mathrm{Na}^{+}+2 \mathrm{~F}^{-}+\mathrm{H}_{2} \mathrm{O}+\mathrm{CO}_{2}
\end{gathered}
$$

Minerals rich in $\mathrm{CaCO}_{3}$ can also favor the dissociation of fluoride from fluorine-containing minerals, as given below:

$$
\begin{aligned}
& \mathrm{CaCO}_{3}+\mathrm{H}^{+}+2 \mathrm{~F}^{-} \rightarrow \mathrm{CaF}_{2}+\mathrm{HCO}_{3}^{-} \\
& \mathrm{CaF}_{2}------\rightarrow \mathrm{Ca}^{+2}+2 \mathrm{~F}^{-} \\
& \mathrm{K}=\left[\mathrm{a}\left(\mathrm{HCO}_{3}^{-}\right] /\left[\mathrm{a}(\mathrm{H}+) \mathrm{X} \mathrm{a}\left(\mathrm{F}^{-}\right)\right]\right.
\end{aligned}
$$

Where $\mathrm{K}$ is an equilibrium constant and is the activity. It is evident that if the $\mathrm{pH}$ is constant, the activity of fluoride is directly proportional to bicarbonate. In the study area fluoride concentration was found between 0.22 to $4.64 \mathrm{mg} / \mathrm{l}$. The maximum value of $4.64 \mathrm{mg} / \mathrm{l} \mathrm{n}$ sample D-7 of Dwarka Sector 19 while the lowest value is recorded in the sample D-20 of Dwarka Sector 12 is $0.22 \mathrm{mg} / \mathrm{l}$. 


\subsection{Chloride ( $\left.\mathrm{Cl}^{-}\right)$}

Chloride-bearing rock minerals such as chlorapatite, which are very minor constituents of igneous and metamorphic rocks, and liquid inclusions, which comprise very insignificant fraction of the rock volume are minor sources of chloride in groundwater. It is presumable that the bulk of the chloride in groundwater is either from atmospheric sources or sea-water contamination. Chloride salts, being highly soluble and free from chemical reactions with minerals of reservoir rocks, remain stable once they enter into solution. Most chloride in groundwater is present as sodium chloride, but the chloride content may exceed due to base-exchange phenomena (Apambire et al., 1997). Calcium and magnesium chloride waters are rather rare. Abnormal concentration of chloride may result due to pollution by sewage waste, salting for certain types of trees like coconuts and leaching of saline in the soil

Chloride concentration in the study area ranges from $53.2 \mathrm{mg} / \mathrm{l}$ (D-7) to 6309.mg/l (D-20). Chloride concentrations of four sources $(\mathrm{D}-7,17,23,24)$ are within maximum desirable limit $(250 \mathrm{mg} / \mathrm{l})$. Five sources (D-10, 12, 16, 19, 20) are out of maximum permissible limit $(1000 \mathrm{mg} / \mathrm{l})$, hence unsuitable for drinking purpose. High chloride content of groundwater is likely to originate from pollution sources such as domestic effluents, fertilizers, septic tanks and from natural sources such as rainfall, the dissolution of fluid inclusions. Increase in chloride level is injurious to people suffering from diseases of heart or kidney (WHO, 1997). Chloride toxicity has been observed in such cases where it is impaired with sodium (EURO, 1978). When the excess chloride concentration is present with excess sodium concentration it may cause congestive heart failure (Brooker and Johnson, 1984; Wesson, 1975) hypertension (EURO, 1978; DNHW, 1978; IOS, 1989). In source D-20 chloride and sodium concentration are high therefore such health effect may occur.

\subsection{Sulphates $\left(\mathrm{SO}_{4}{ }^{2-}\right)$}

The main source of sulphate in the groundwater is presence of gypsum as a part of evaporites sequence present in quaternary sediments as well as in underlying basement rocks (Dey, 1991). Sulphate concentration of the study area was found between 10 to $1046 \mathrm{mg} / \mathrm{l}$. The maximum concentration was found in source D-2 of Dwarka Sector 14 and minimum in source D-7, 18, 23, 24. From table it is clear that only three sources (D-2, 10, 20) have its concentration above maximum permissible limit $(400 \mathrm{mg} / \mathrm{l})$. The sulphate concentrations in remaining sources are within maximum desirable limit. The concentration of sulphate is likely to react with human organs if the value exceeds the maximum allowable limit of $400 \mathrm{mg} / \mathrm{l}$ and causes a laxative effect on human system with the excess magnesium in groundwater. Dehydration has been reported by Final, 1980 as a common side effect of high sulphate consumption. Carthartic effects are also experimented on people consuming drinking water containing sulphate concentration more than $600 \mathrm{mg} / \mathrm{l}$ (Chaein, 1968; USDHEW, 1962; USEPA, 1985).

\subsection{Nitrate and Nitrite as $\mathrm{N}$}

Generally the major sources for nitrate in groundwater include domestic sewage, runoff from agricultural fields, and leachates from landfill sites (Lee et al., 2003; Jalali, 2005). Nitrate in the study area was found in high concentrations. It was recorded in the range of 10.8 to $147 \mathrm{mg} / \mathrm{l}$ nitrate as $\mathrm{N}$ as shown in table 1 . Nitrate itself does not show toxic effect but in human body when it is reduced to nitrite, it creates various serious unhealthy effects. Nitrate has been found to react with nitro stable compounds to form $\mathrm{N}$ - nitroso compounds. Most of these compounds have been found to be carcinogenic. United State National Research Council (USNRC) has found an association between high nitrate intake and gastric and or Oesorphageal cancer. The major biological effect of nitrite in human is its involvement in the oxidation of normal hemoglobin to methaemoglobin, which is unable to transport oxygen. When the concentration of methaemoglobin reaches $10 \%$ of that of hemoglobin; the condition called mathaemoglobinaemia or blue baby syndrome, cause cyanosis and at higher concentration asphyxia (Sallman, 1957; Craun et al., 1981). Such reports of other health disorder namely non Hodgkin's lymphoma (Weisenbeage, 1991) has increased infant mortality (Super et al., 1981) and hypertension (Malberg et al., 1978) have also been recorded. The nitrite concentration varies from 0.00 to $0.12 \mathrm{mg} / \mathrm{l}$.

\subsection{Silicate and Phosphate}

Phosphorus originates from the weathering of local rocks and fertiliser use. The concentration of phosphate in water samples varied from below detection limit (BDL) to $2.98 \mathrm{mg} / \mathrm{l}$. The highest concentration is measured in D-6 of Dwarka Sector 18.

Silica is one of the most common rock forming groups of minerals on earth. Its concentration is expressed in terms of $\mathrm{SiO} 2$. The concentration of silica varies 61 to $1013 \mathrm{mg} / \mathrm{l}$. The minimum and maximum concentration was observed in D-7 of Dwarka Sector 19 and D-12 of Dwarka Sector 22 respectively.

\subsection{Water Quality Index:}

A number of indices have been developed to summarize water quality data in an easily expressible and easily understood format. A water quality index is a means to summarize large amounts of water quality data into simple terms (e.g., good) for reporting to management and the public in a consistent manner. Twenty seven samples were collected from Dwarka sub city and the physicochemical parameters of these samples including $\mathrm{pH}$, Total hardness, calcium, magnesium, Bicarbonate, chloride, Fluoride, Nitrate, Sulphate, sodium and potassium were cumulated into a single parameter known as Water Quality index(W.Q.I). 
The Ground Water Quality index for drinking purposes is calculated by the following steps:

Weight is assigned to the parameters under consideration (wi). These weights indicate the relative harmfulness when present in water. The maximum weight assigned is 5 and minimum is 1.The relative weights $(\mathbf{W i})$ are calculated as per the formula:

$$
\mathbf{W i}=\frac{w i}{\sum_{1}^{n} w i}
$$

\begin{tabular}{|lccc|}
\hline $\begin{array}{l}\text { Chemical } \\
\text { parameters }\end{array}$ & $\begin{array}{c}\text { BIS, 10500, } \\
\mathbf{2 0 1 2}\end{array}$ & $\begin{array}{c}\text { Weight } \\
\text { (wi) }\end{array}$ & $\begin{array}{c}\text { Relative } \\
\text { weight }(\mathbf{W i )}\end{array}$ \\
pH & $6.5-8.5$ & 4 & 0.129032 \\
Total & 300 & 2 & 0.064516 \\
hardness & & & \\
Calcium & 75 & 2 & 0.064516 \\
Magnesium & 30 & 2 & 0.064516 \\
Bicarbonate & 244 & 3 & 0.096774 \\
Chloride & 250 & 3 & 0.096774 \\
Fluoride & 1 & 4 & 0.129032 \\
Nitrate & 45 & 5 & 0.16129 \\
Sulphate & 150 & 4 & 0.129032 \\
Sodium & 20 & 1 & 0.032258 \\
Potassium & 10 & 1 & 0.032258 \\
& & $\sum \mathbf{w i}=\mathbf{3 1}$ & $\sum \mathbf{W i}=\mathbf{1}$ \\
\hline
\end{tabular}

Note: All values are in $\mathrm{mg} / \mathrm{l}$ except $\mathrm{pH}$

1. Now each parameter was assigned a quality rating scale (qi)as per the following formula

$$
\mathbf{q i}=(\mathrm{Ci} / \mathrm{Si}) \times 100
$$

2. Where, $C i=(c i-v i) ; c i-i s$ the value of each parameter as observed experimentally.

$v \boldsymbol{i}$-is the base value for each parameter (which Is 0 for all parameters except pH for which it is 7) and $S i=(s i-v i) ; s i$-is the standard value as recommended by BIS 10500, 2012.

3. The sub index (S.Ii) of each parameter for a place is thus calculated as:

S.I $\mathbf{I}_{\mathrm{i}}=\mathbf{q i}$ X Wi

And the water quality index of each station is calculated as

$$
\text { W.Q.I= } \sum_{1}^{n} \mathbf{S} . \mathbf{I i}
$$

Where $\boldsymbol{n}$-is the number of parameters being assessed by Water Quality Index (WQI).

From the comparative analysis of WQI values for all sampling location, it was observed that WQI values varies from 58.3 to 907.2 the maximum value of 907.2 is observed in the sample D-20 of Dwarka Sector 12 while the minimum is recorded in D-17 of Dwarka Sector 6 is 58.3.

Application of Water Quality Index (WQI) in this study has been found useful in assessing the overall quality of water and to get ride of judgment on quality of the water. This method appears to be more systematic and gives comparative evaluation of the water quality of sampling stations. It is also helpful for public to understand the quality of water as well as being a useful tool in many ways in the field of water quality management. 


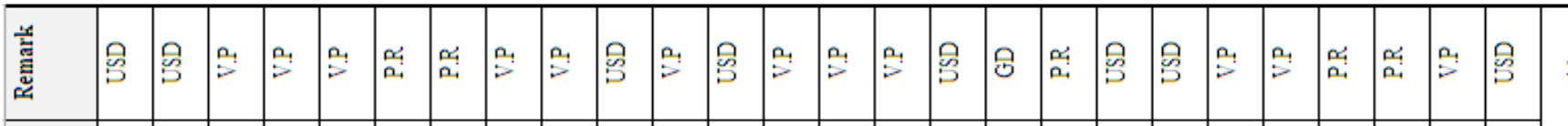

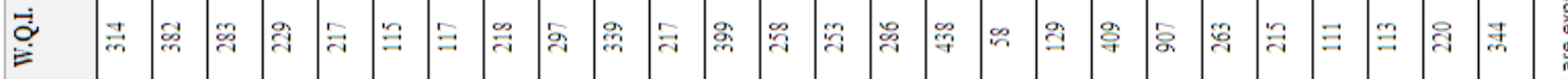

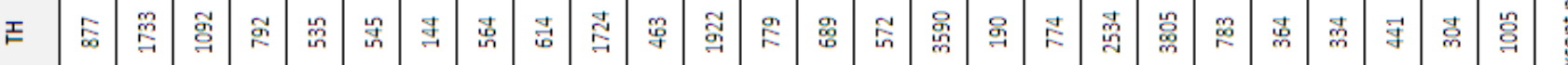

홍

๘

क

을

\%

茥

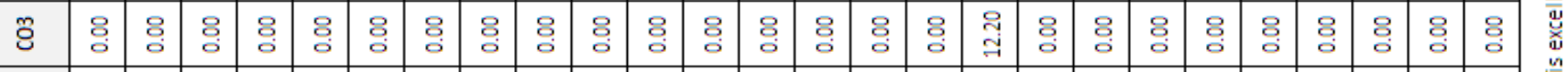

总 兽 旁

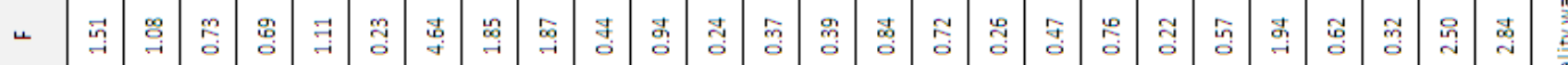

ஜ

-

ธ ऽ

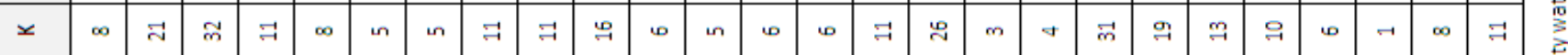

旡 吉

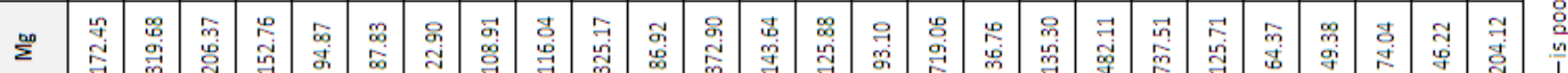

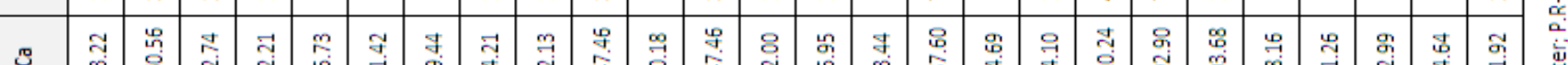

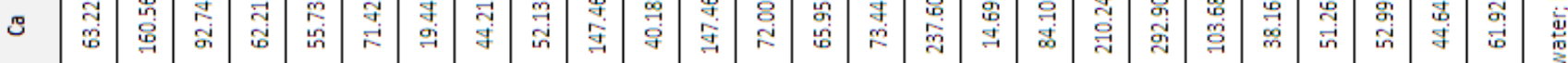

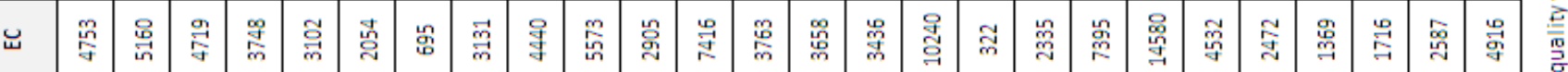

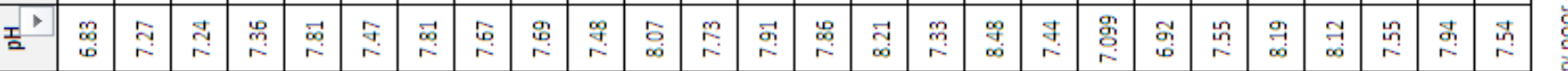

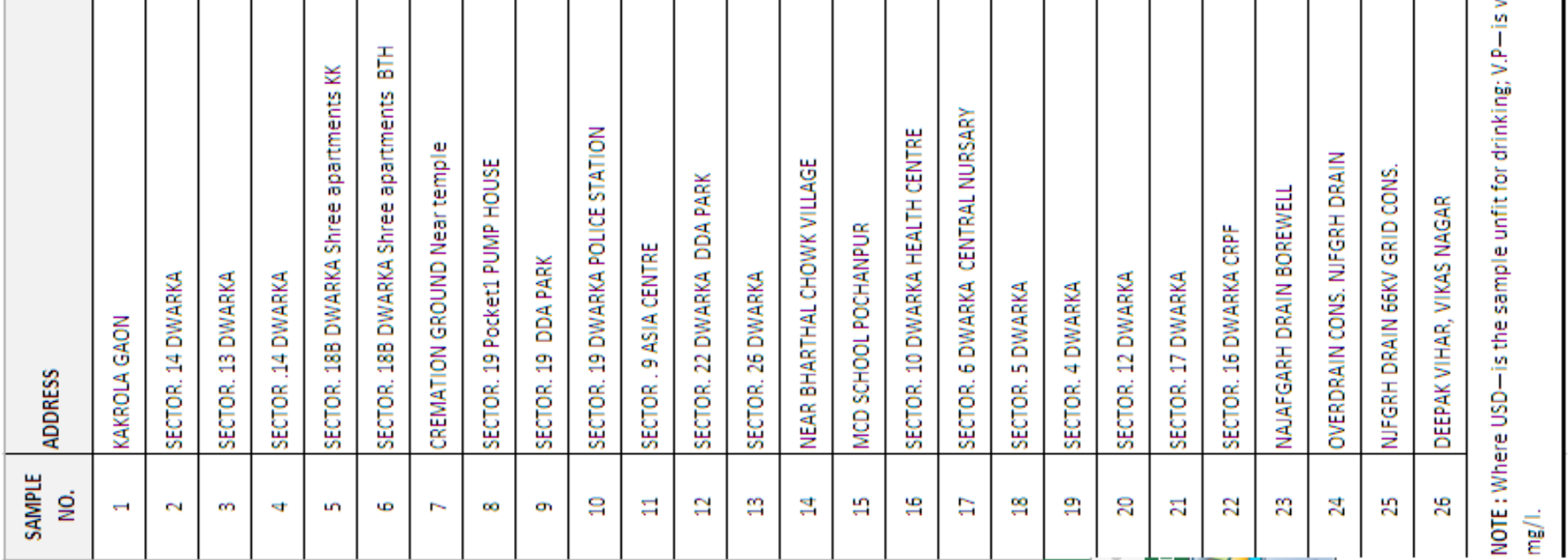




\begin{tabular}{|c|c|c|c|}
\hline $\begin{array}{c}\text { WQI } \\
\text { value }\end{array}$ & $\begin{array}{c}\text { Water } \\
\text { quality }\end{array}$ & $\begin{array}{c}\text { No of } \\
\text { water } \\
\text { samples }\end{array}$ & Detail of samples \\
\hline$<50$ & Excellent & 0 & \\
\hline $\begin{array}{l}50- \\
100\end{array}$ & Good water & 1 & D17 \\
\hline $\begin{array}{l}100- \\
200\end{array}$ & poor water & 5 & D- $6,7,18,23,24$ \\
\hline $\begin{array}{l}200- \\
300\end{array}$ & $\begin{array}{l}\text { very poor } \\
\text { water }\end{array}$ & 12 & $\begin{array}{l}\text { D-3,4,5,8,9,11,13, } \\
14,15,21,22,, 25\end{array}$ \\
\hline$>300$ & $\begin{array}{l}\text { Water } \\
\text { unsuitable } \\
\text { for drinking }\end{array}$ & 8 & D-1,2,10,12,16,19,20.26 \\
\hline
\end{tabular}

From the water quality index parameter it has been observed that $\mathbf{3 0 . 7 7 \%}$ of samples tested have been found unfit for drinking (D-1,2,10,12,16,19,20,26), While 46.15\% samples have been found to have very poor quality and $\mathbf{1 9 . 2 3 \%}$ of samples belongs to the poor category of water quality.

\section{ACKNOWLEDGEMENTS}

We the author(s) are thankful to Director Training and Superintending Engineer, (HOC), of Central Water Commission, for providing laboratory facilities and also thankful to the other working staff for their guidance while performing the various analysis.

\section{REFERENCES}

[1] Apambire, W.B., Boyle, D.R. and Michel, F.A.(1997). Geochemistry, genesis, and health implications of fluoriferous groundwater in the upper regions of Ghana. Environ Geol, 33(1):13-24.

[2] APHA (2012). Standard Method for Examination of Water and Wastewater (22nd Edition). Washington, DC, USA: American Public Health Association.

[3] Arif, M., I. Hussain, J. Hussain, S. Sharma, and S. Kumar. (2012). "Fluoride in the Drinking Water of Nagaur Tehsil of Nagaur District, Rajasthan, India." Bulletin of Environmental Contamination and Toxicology 88: 870-875.

[4] Banar, M., Aysun, O. and Mine, K. (2006). Characterization of the leachate in an urban landfill by physicochemical analysis and solid phase microextraction. GC/MS. Environ. Monitor. Assess., 121:439-459. DOI: 10.1007/s10661-005-9144.

[5] Brooker M.P., Johnson, P.C. (1984). Behaviour of phosphate, nitrate, chloride and hardness in 12 Welsh rivers. Water research, 1984, 18(9):1155-1164.

[6] Brown, E., Skougstad, M. W., \& Fishman, M. J. (1974). Method for collection and analysis of water sample for dissolved minerals for dissolved minerals and gases (Book No. 5). Washington, DC: US Department of Interior.
[7] Bureau of Indian Standard (BIS) (2012). Indian standard specification for drinking water (pp. 2-4). Delhi: BIS, IS 10500.

[8] Chaein, L. 1968. Canadian Medical Association Journal, 99, 102.

[9] Craun G.F., Grathouse, D.G. and Gunderson, D.H. (1981). Methemoglobin levels in young children consuming high nitrate well water in the United States. Int J Epidemiol, 10: 309-325.

[10] Department of National Health and Welfare (Canada) (1978). Guideline for Canadian drinking water quality. Supporting documentation. Ottawa

[11] Fingl, E. (1980). Laxatives and cathartics, In Gilman Ag et al., eds Pharmacological basis of therapeutics, New York NY, MacMillan publishing,

[12] Handa B.K. (1975). Geochemistry and genesis of fluoride containing groundwater in India. Ground Water 13:275-281

[13] Husain, J., Sharma, K.C., Husain, I., Ojha, K.G. and Vaidya, V.K. (2001). Physico-chemical characteristics of water from bore wells of an industrial town Bhilwara, Rajasthan: a correlation study. Asian J Chem, 13: 509\{512.

[14] Hussain, I., Arif, M.and Hussain. J. (2012). "Fluoride Contamination in Drinking Water in Rural Habitations of Central Rajasthan, India." Environmental Monitoring and Assessment 184: 5151-5158.

[15] Hussain, J., Sharma, K.C. and Hussain, I. (2010). "Fluoride and Health Hazards: Community Perception in a Fluorotic Area of Central Rajasthan (India): An Arid Environment." Environmental Monitoring and Assessment 162: 1-14.

[16] Hussain, J., Sharma, K. C. and Hussain, I. (2003). Fluoride distribution in groundwater of Raipur Tehsil in Bhilwara District. International Journal of Bioscience Reports, 1(3), 580-587.

[17] Hussain, J., Sharma, K. C. and Hussain, I. (2004). Fluoride in drinking water and its ill affect on Human Health: A review. Journal of Tissue Research, 4(2), 263-273

[18] Hussain, J., Sharma, K. C. and Hussain, I. (2005a). Fluoride distribution in groundwater of Banera Tehsil in Bhilwara District, Rajasthan. Asian Journal of Chemistry, 17(1), 457-461.

[19] Hussain, J., Sharma, K. C., Ojha, K. G. and Hussain, I. (2000). Fluoride distribution in ground waters of Sirohi district in Rajasthan. Indian Journal of Environment and Eco-planning, 3(3), 661-664.

[20] Hussain, J., Shrama, K. C., Arif, M., and Hussain, I. (2007). Fluoride distribution and modeling using best subset procedure in Nagour District of Central Rajasthan, India. In The XXVIITH conference of the international society for fluoride research (ISFR XXVII), 9-12 October, 2007. Beijing, China. 
[21] International Organization for Standardization, (1989). Water quality determination of chloride. Geneva, 1989 (ISO 9297:1989).

[22] Jalali M. (2005). Nitrate leaching from agricultural land in Hamadan, western Iran. Agric Ecosyst Environ 110:210-218

[23] Lee S.M., Min, K.D., Woo, N.C., Kim Y.J. and Ahn, C.H. (2003). Statistical assessment of nitrate contamination in urban groundwater using GIS. Environ Geol 44:210-221

[24] Malberg, J.W., Suvage, E.P. and Osteryoung, J. (1978). Environmental Pollution, 15, 155

[25] Oregon Department of Environmental Quality , Water Quality Division, (July 2004), "Oregon's 2004 Water Quality Assessment Section 305(b)

[26] Rama Rao N.V. (1982). Geochemical factors influencing the distribution of fluoride in rocks, soil and water sources of Nalgonda district. AP Thesis, Osmania University, Hyderabad

[27] Rammohan Rao N.V., Rao N, Suryapraksha Rao K. and Schuiling R.D. (1993). Fluorine distribution in waters of Nalgonda District, Andhra Pradesh, India. Environ Geol 21:84-89

[28] Sallman, T.A. (1957). Manual of pharmacology, 8th ., W.B. Saunders, Philadelphia

[29] Sawyer, C.N and McCarty, P.L (1967): Chemistry for Sanitary Engineers.2nd edition. McGraw-Hill, New York, p.518.

[30] Saxena V.K., Ahmed ,S. (2003). Inferring the chemical parameters for the dissolution of fluoride in groundwater. Environ Geol 43:731- 736

[31] Saxena V.K., Ahmed, S. (2001) Dissolution of fluoride in groundwater: a water reaction study. Environ Geol 40:1084-1087

[32] Sodium, chlorides, and conductivity in drinking water a report on a WHO working group. Copenhagen, WHO Regional office for Europe, (1978) (EURO report and studies 2).

[33] Sujatha, D. (2003) Fluoride levels in the groundwater of the southeastern part of Ranga Reddy district, Andhra Pradesh, India. Environ Geol 44:587-591

[34] Super, M., Heese, H., Mackenzie, D., Dempster, W.S., duPless, J., and Ferreira, J.J., 1981, An epidemiologic study of well-water nitrates in a group of South West African Namnian infants: Water Resources, v. 15, p. $1,265-1,270$.

[35] Tiwari T.N. and Ali, M. (1988). Water Quality Index for Indian Rivers. In Ecology and Pollution in Indian Rivers. R.K. Trivedy edited. Ashish Publishing House, New Delhi. pp: 271-286.

[36] US Department of Heath, Education, and Welfare, (1962). Drinking water standered-1962, Washington, DC, US Government Printing office, 1962 (Public Health service Publication No. 956).

[37] US Environmental Protection Agency, (1985). Ferderal register, 50 (219), 46936.
[38] Wesson, L.G. (1975). British. J. Cancer, 30, 322

[39] World Health Organization (WHO): (1997), Guideline for Drinking Water Quality, 2nd ed., Vol. 2 Health criteria.

\section{BIOGRAPHIES}

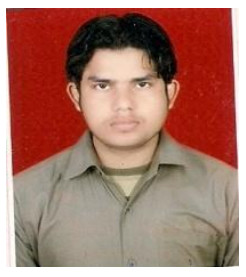

I Ravi Kant Dubey is a student of Environmental Engineering from Ch.B.P.Government Engineering College, jaffarpur New Delhi. Research interests includes Water and Waste water technologies and processes, designing of civic facilities \& solid waste management, air pollution, environmental impact assessment etc. Involved in several work related to waste water studies and processes related to it. Keen interested in phenomenon's related to atmospheric sciences and their interaction.

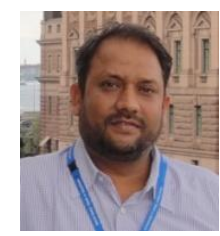

Dr. Jakir Hussain M.Sc.(Chemistry), Ph.D in Environmental Chemistry currently working as Assistant Research Officer ,National River Water Quality Laboratory, Yamuna Basin Organization, Central Water Commission, New Delhi. He has more than 185 publications in national/International journals \& conferences of repute. He is involved in the several works related to fluoride contamination \& health hazards, characterization of waste water and evolution of drinking water, Industrialization and Urbanization Impacts on the Aquatic Ecosystem: Problem and Prevention.

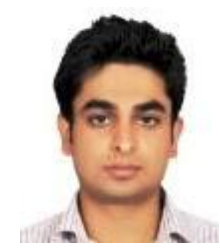

Nishchay Malhotra is a student of Environmental Engineering from Ch.B.P.Government Engineering College, jaffarpur New Delhi. Keen interested in water \& waster water technologies and global positioning system, air pollution etc.

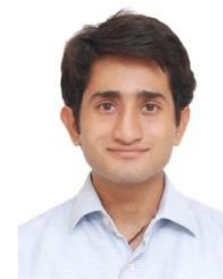

Ankur Mehta is a student of Environmental Engineering from Ch.B.P.Government Engineering College, jaffarpur New Delhi. Research interest includes Process designing of various Waste water technologies and GIS based studies. 